\title{
少菌型ハンセン病の 1 例
}

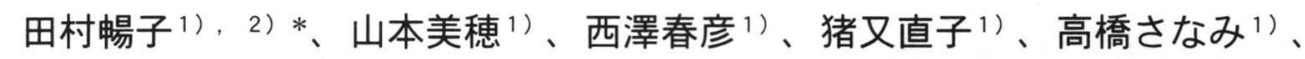

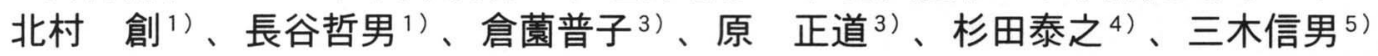

1）横浜市立大学医学部附属市民総合医療センター皮膚科

2 ) 横須賀北部共済病院皮虐科

3 ）横浜市立大学附属市民総合医療センター病理部

4 ）横浜市立大学医学部附属病院皮膚科

5 ）三木クリニック

〔受付：2003年 8 月 1 日〕

キーワード：ハンセン病、少菌型、フィリピン

症 例：31歳、女性。フィリピン出身、数年前か ら日本に在住。

主 訴: 顔面、頸部の皮疹。

初診: 平成 12 年 9 月 4 日。

既往歴：特記すべき事なし。

家族歴：ハンセン病を思わせる症状を呈する者な し。

現病歴：初診の約 1 年前の平成 11 年 7 月頃から左 大腿部、篮部右側に、平成 12 年 4 月頃からは頸部 に自覚症状の無い紅色局面が出現した。初診の約 2 力月前の平成 12 年 7 月頃からは顔面にも紅色局 面が出現したため某医皮膚科受診し、外用薬を処 方された。著変ないため、同月に某内科医院受診 し、マレイン酸クロロフェニラミン等を処方され た。これらの内服にても著変ないため前医皮膚科 再診し、当科に紹介され受診した。

現 症：おとがい部に境界明瞭で軽度隆起し、表 面に光沢を帯びた紅色局面を認めた。頸部右側に 境界明瞭な鱗屑を伴う紅色局面を認めた（図 1 a）。慰部右側に $3 \mathrm{~cm}$ 大の紅色局面を、左大腿部

*Corresponding author : 横須賀北部共済病院皮膚科

干237-0076 横須賀市船越町1-8

Tel:046-861-3161 Fax:046-861-3167
に $10 \mathrm{~cm}$ 大の境界明瞭で周辺部に紅色調の強い扁平 隆起性局面を認めた（図 $1 \mathrm{~b}$ )。計 4 個の皮疹部 全てにおいて触覚と痛覚の低下が認めた。右の尺 骨神経に数珠状の肥厚を認めた。

病理組織学的所見: 表皮に著変無く、真皮直下か ら真皮全層にわたり神経、血管および付属器周囲 に密な炎症細胞浸潤を島嶼状にみとめた（図 2 a)。炎症細胞は多数のリンパ球と類上皮細胞、 巨細胞からなり、いわゆる類結核性肉芽腫の像を 呈していた（図 $2 \mathrm{~b}$ )。乾酪壊死は認めなかっ た。神経周囲には多数のリンパ球と類上皮細胞が 浸潤していた。病理標本のZiehl-Neelsen染色では 抗酸性桿菌は認めなかった。

臨床検査成績 : 末梢血、生化学的には、異常所見 はみられなかった。皮膚組織標本からDNAを抽出 しpolymerase chain reaction (PCR)法をおこなっ たところ $157 \mathrm{bp}$ のらい菌特異的DNAが検出され た。

以上よりハンセン病と診断した。世界保健機構 （WHO）の分類ではpaucibacillary PB（少菌 型）、Ridley-Jopling の免疫学的分類ではBorderline Tuberculoid type BTと診断した。

治療および経過：オフロキサシン(OFLX)600mg/ 日で治療を開始したが、患者の以前からの予定ど 
うりに、翌週にフィリピンに帰国し、当地で治療 を続けることとなった。

考 按：日本におけるハンセン病新患者数は近年 減少しており、特に日本人では年間 10 人以下と なっている11。しかし、在日外国人の新患者は最 近増加している。1996年 4 月のらい予防法廃止に 伴い、一般医療機関においてハンセン病患者を診 断、治療する機会が増えている ${ }^{2)}$ 。発展途上国か ら入国する外国人が増加している現在、ハンセン 病は頭に置いておかなければいけない疾患の 1 つ

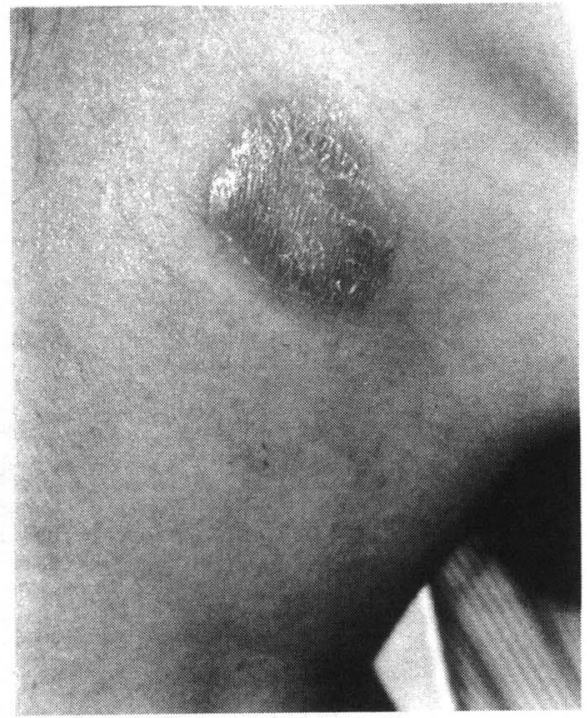

図 $1 \mathrm{a}$ 頸部右側の境界明瞭な鱗屑を伴う紅色局面。

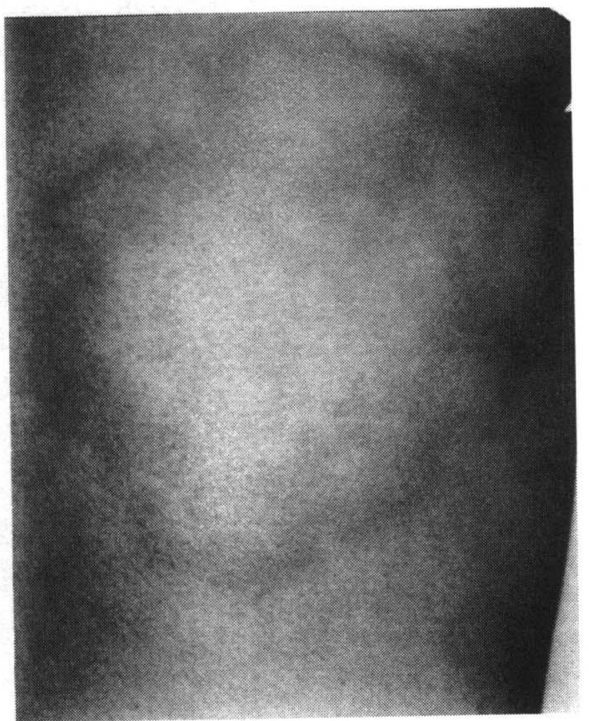

図 $1 \mathrm{~b}$ 左大腿部の境界明瞭で周辺部に紅色調の強い扁 平隆起性局面。
であり、神経障害による後遺症を残さないために も皮膚科医の役割は重要だと考えた。

\section{文 献}

1 ) 石井則久、杉田泰之、中嶋 弘：ハンセン病 新患動向-1993年から1997年まで-. 日皮会誌 $109 ; 763-767,1999$.

2 ) 石井則久：これからのハンセン病. 日皮会誌 107 ; 943-948, 1997.

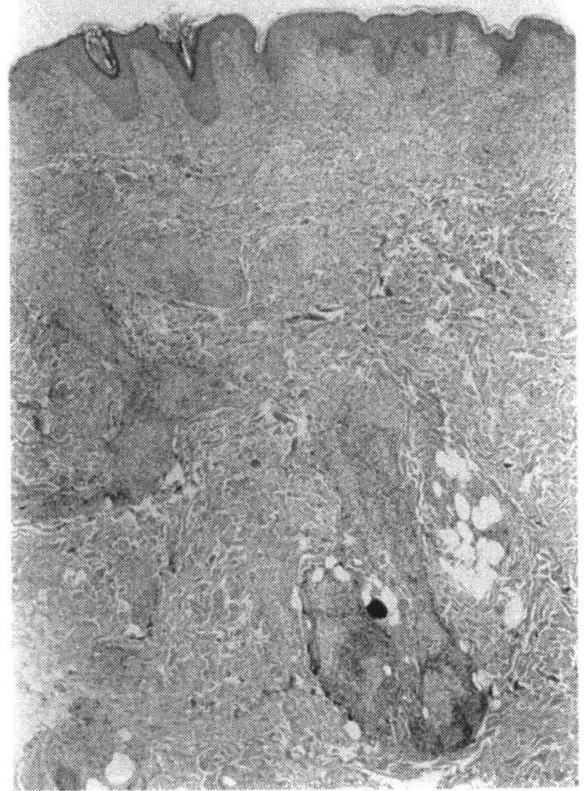

図 $2 \mathrm{a}$ 病理組織HE標本弱拡大像。真皮直下から真皮全 層にわたり神経、血管および付属器周囲に密な 炎症細胞浸潤を島嶼状に認める。

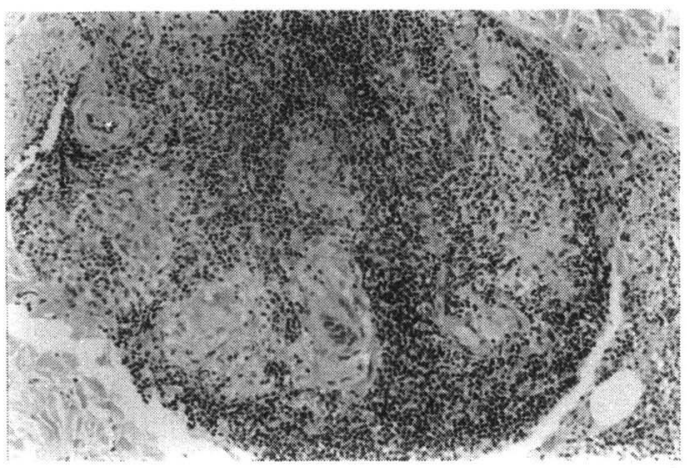

図 $2 b$ 病理組織HE標本強拡大像。多数のリンパ球と類 上皮細胞、巨細胞が浸潤し、類結核性肉芽腫を 形成。 


\title{
A Case of Paucibacillary Leprosy
}

\author{
Nobuko Tamura 1), 2)*, Miho Yamamoto1), Haruhiko Nishizawa 1), \\ Naoko Inomata 1), Sanami Takahashi 1), Hajime Kitamura 1), \\ Testuo Nagatani 1), Yasuko Kurasono ${ }^{3)}$, Masamichi Hara ${ }^{3)}$, \\ Yasunori Sugita ${ }^{4)}$, Nobuo Miki ${ }^{5)}$ \\ 1) Department of Dermatology, Yokohama City University Medical Center \\ 2) Division of Dermatology, Yokosuka Hokubu Kyosai Hospital \\ 3) Department of Pathology, Yokohama City University Medical Center \\ 4) Department of Dermatology, Yokohama City University School of Medicine \\ 5) Miki clinic
}

[Received: 1 August 2003]

Key Words : leprosy, paucibacillary, philippine

We report a case of leprosy. A 31-old-filippine female present with 5 month history of an erythematous plaqe on her right neck. Examination showed 4 erythematous plaqes with her. A histological examination of the skin lesion of hir thigh revealed granulomas around nerve and skin appendages which consist of lymphocytes, epidermoid cells and giant cells. Although no acid fast bacilli were not demonstrated by skin biopsy with Ziehl-Neelsen staining, the Mycobacterium leprae-specific DNA was detected by polymerase chain reaction method. A diagnosis of paucibacillary leprosy had made. We started treatment with ofloxacin but she return to filippine soon.

*Corresponding author :

Yokosuka Hokubu Kyosai Hospital

1-8 Funakoshi-cho, Yokosuka-shi, Japan

Tel:046-861-3161,Fax:046-861-3167 